\title{
The Specific Composition of Micromycetes Contaminants of Children Foods in Syria and there Toxigenic Activity
}

\author{
Youssef $\mathrm{O}^{* 1}$, and Hamed $\mathrm{F}^{2}$ \\ ${ }^{1}$ The General Commission for Scientific Agricultural Research (GCSAR), Al-Qamishly Agricultural Research Center, \\ Al-Qamishly, Syria \\ ${ }^{2}$ The General Commission for Scientific Agricultural Research (GCSAR), Food science department, Damascus, Syria
}

*Corresponding author: Youssef O, The General Commission for Scientific Agricultural Research (GCSAR), Al-Qamishly Agricultural Research Center, Al-Qamishly, Syria, E-mail: om_youssef@yahoo.com

Citation: Youssef O, Hamed F (2018) The Specific Composition of Micromycetes-Contaminants of Children Foods in Syria and there Toxigenic Activity. J Plant Sci Crop Protec 1(1): 101. doi: 10.15744/2639-3336.1.101

Received Date: February 08, 2018 Accepted Date: March 14, 2018 Published Date: March 19, 2018

\begin{abstract}
For the investigation of micromycetes-contaminants in children foods and their toxigenic activity, 173 samples of children foods traded in local markets in al-Hasakah governorate -northeastern Syria- were collected and tested during the period (2011-2012). The tested samples were included in 4 food groups: oily seeds ( 35 samples), potato \& maize chips (53 samples), biscuits ( 45 samples) and powdered milk \& sugars (40 samples).The Sample investigation was undertaken in the plant diseases laboratory in Al-Qamishli Agricultural Research Center. The results of the analysis showed that most of the samples tested were contaminated with fungi in varying degrees ranged between $1 \times 10^{2}$ and $5 \times 10^{7}$ spore / gram of food substance. Only $2.3 \%$ of the samples tested exceeded $10^{4}$ spore / gram of food substance. The results of the investigation also led to isolating and identifying 566 isolates to 21 different species of fungi, belonging to 8 fungal genuses, 4 families, 3 orders \& 2 classes of fungi (Zygomycetes \& Hyphomycetes). The largest number of fungal species belonged to the genuses: Aspergillus (7 species) \& Penicillium (6 species), to a lesser extent the genus: Fusarium ( 3 species) and one species for each of the genuses: Alternaria, Rhizopus, Mucor, Stemphilium \& Cladosporium. The species (A. niger, A. flavus, $P$. cyclopium, $R$. stolonifer and A. alternate) were detected on all the tested samples. The toxicity test conducted by biological methods for 82 pure fungal isolates: 28 of Aspergillus flavus, 10 of A.niger, 5 of A.ochraceus, 15 of Penicillium spp, 7 of A. alternate and 17 of Fusarium spp. in laboratory conditions indicated that 26 isolates (31.7\%) showed different rates of toxicity on germination of chickpea and corn seeds and on activity of Bacillus sp. in lab conditions, which indicates that the tested isolates had produced toxic substances. There is a need to undertake suitable actions to reduce fungi activity to prevent the potential health hazards of the poisonous mycotoxins on the consumer.
\end{abstract}

Keywords: Children foods; Contamination; Fungi; Mycotoxins; Syria

\section{Introduction}

Children foods are the foundation of their health and safety, therefore, preserving the quality and safety of these foods by keeping them away from damage \& corruption sources has become a priority at the present time, especially since a lot of organisms such as fungi are active during processing \& storage and are causing massive damage to those foods during the different stages of preparation, production and storage. The danger of fungi doesn't lie in their presence but in their toxic secretions through their different stages of growth on foods, these toxins are called Mycotoxins [1,2].

The problems of Mycotoxins first appeared during world war II, when people in Russia and other places in the world consumed rotten grains and caused them skin ulcers, bleeding, liver \& kidney failure and in a lot of times it lead to death of both humans and farm animals [3].

A lot of foods are exposed to fungal infections and consequently, to mycotoxin- contamination, which leads to their damage. It has been shown that Peanuts, soybeans, wheat and maize are the most sensitive foods to contamination, in addition to milk, and most likely meat \& eggs but indirectly, when farm animals feed on aflatoxin- contaminated feed, they're transferred to meat \& eggs in their original form or as other metabolites. Aflatoxins are mainly produced by isolates of two fungi: Aspergellus flavus \& Aspergellus parasticus, and most of Aspergellus flavus isolates produce aflatoxin B1 [4].

The growth and spread of fungi in foods depends basically on two factors, temperature and humidity as indicated by [5]. Many studies have been done in order to determine the optimal growth conditions for the fungus Aspergellus flavus and have indicated that the optimal relative humidity to produce aflatoxins is $85 \%$ and the minimum, optimal and maximum temperature for aflatoxin production is $12{ }^{\circ} \mathrm{C}, 27^{\circ} \mathrm{C}$, and $42^{\circ} \mathrm{C}$ respectively [6,7]. 
A lot of references refer to the relation between aflatoxins and liver infections \& cancers, it may also affect the sexual performance and in some cases it can 118 cause skin \& kidney diseases [8]. A great 119 evidence of liver infection in humans is what happened to hundreds of people 120 in northwest India in 1974 as a result of consuming aflatoxin-contaminated 121 maize with concentrations higher than $15 \mathrm{mg} / \mathrm{kg}$. The presence of these toxins 122 in different concentrations in different kinds of foods especially grains and grain-erived foods and a lot of poisoning cases were considered as an obstacle in trading these foods which made a lot of countries and organizations set limits and thresholds regarding the presence of these toxins in foods and 126 feeds, and the limits varied according to the type of material, its use and the 127 kind of toxins it holds. Generally, the maximum limit permitted for aflatoxins 128 is $5 \mathrm{mg} / \mathrm{kg}$ for foods and $20 \mathrm{mg} / \mathrm{kg}$ for feeds [3].

The extend of poisoning varies from one person to another according to dietary habits and according to the consumption of aflatoxin-contaminated foods, and thus, children are the most exposed to contamination and consequently to poisoning since most of children's foods contain dried milk or maize. These materials are the most vulnerable to aflatoxin-contamination, on the other hand, the lowest concentrations of aflatoxins might cause great poisoning effects on children because of their small body sizes as they're measured relatively to body weight $[9,10]$.

In addition to aflatoxins, there is a group of fungal toxins mainly produced by various species of Fusarium which are the most producers of these toxins. The history of these fungi's toxicity goes back to 1916 when vomiting \& poisoning symptoms appeared on human after consuming a bread made of Fusarium graminearum-infected wheat, and also to 1928 when a large number of birds got poisoned in the United States $[11,12]$.

In 1930s, poisoning symptoms appeared on people in Russian and it happened again during world war II, when maize crops were left in fields because of the lack of manpower and so, the crop was exposed to snow, moisture and fungi, the rate of infection among population was $10 \%$ at that time, and in some places death rate reached $50 \%$ among the infected people $[3,13]$.

The Fusarium fungi have a feature of adapting to different environments, they can be saprophytic or parasitic to different plant tissues and cause different damages which made them gain a global importance, they can cause decomposition of roots and rottenness to the stem, leaves, seeds and fruits, they may also stop the growing and fruiting of plants, in addition to the health damages caused by the activity of these fungi in corps in fields and stores since they produce a lot of toxins that some of which have an importance in some practical aspects like Zearalenons and Trichothecins [1]. The spread of fungal toxins in foods depends on the existence of certain fungal isolates, environmental factors, geographical conditions, the conditions of production \& storage, and the type of the food substance especially that some of foods substances stimulate the growth of fungi more than others like grains and their derivatives which form an essential part of the human's diet and a key element of farm animal's feed [14,15]. Zearalenons are mainly and naturally produced by F.graminearum, while in laboratory conditions it was found in small quantities for the species F.moniliforme, F.tricinctum, F.oxysporum, F.sporotrichioides and F.culmorum [16]. In natural conditions, Zearalenon mainly contaminates seeds as it's found in fair amounts in maize, wheat, oats, barley and in many foods and feeds in many European countries as well as in America, Canada, Australia, India, Japan and South Africa [17. The rest of Zearalenon derivatives (13 components) were extracted from the pure cultures of these fungi in laboratory conditions.

The foods that include maize in their composition are the most vulnerable to be contaminated by Zearalenons which leads some researchers to associate the basic substance (maize) with the presence of the fungus F.germinearum. Noting that most of children's foods include maize in their composition, it's essential to keep inspecting these foods to prevent the contamination with fungi and subsequently with their toxic secretions. In a study conducted in 1977 , al-Hiti found that $27 \%$ of the grain stores in Iraq were infected with Zearalenons [2]. Youssef (2000) [18] also indicated that 27.8\% of the tested maize samples in Armenia in the period of 1999 - 2000 were infected with Zearalenons and in different concentrations that exceeded the acceptable limits. Many cases of farm animals' poisoning which resulted from feeding on infected feeds were a real indication of producing contaminants by the above mentioned fungi. Consuming foods that are infected with these contaminants results in various health hazards; they can cause diseases called Mycotoxicoses. Aspergellus, Penicillium and Fusarium are the most significant genera that produce toxins. And of these toxins we can mention: aflatoxins, which are considered the most serious, dangerous and widely spread, Trichothecins, Zearalenons, Ochratoxins, Cittinin and Patulin [3,19].

\section{Research objectives}

Identifying the fungi species that infect children's foods and determining their frequency degrees. Studying the toxic activity of the main fungi isolated from children's foods.

\section{Materials \& Methods}

\section{Sampling}

The research was carried out in the laboratory of Plant Pathology at the Agricultural Research Center in Al-Qamishly during the period 2011-2012, where 173 samples of children's foods, traded in the local markets in Hasaka province northeast Syria, were collected in the conditions of direct consumption. The samples were collected according to a special form that included information about the type of the material, its source, the period of its storage and the date collected according to international standards set by the International Seed Testing Association ISTA in 1976 [1] in addition to the French sampling standards [20]. The 
tested materials were included into 4 group sets of foods, the first is oily seeds ( 35 samples), the second is potato \& maize chips ( 53 samples), the third is biscuits (45 samples) and the fourth is candy and dried milk (40 samples).

\section{Fungi isolation}

The serial dilution of the spores' solution was carried out and followed by the direct planting of the food substances on the artificial nutritional media to study their cultural characteristics like: speed of growth, color, color of the opposite surface, their secretions as well as the morphological characteristics of the various fungi organisms under the optical microscope. To develop \& isolate the fungi, the following cultures were used: PDA (Potato - Dextrose - Agar), Agar Czapek, liquid Czapek environment with the addition of $10 \mathrm{mg}$ of the antibiotic tetracycline per 1 liter of the nutritional environment. Prepared dishes were incubated to isolate \& develop fungi at the temperature $(25-28)^{\circ} \mathrm{C}$ for 5-7 days $[1,21]$.

\section{Fungi classification}

The fungi were classified according to the morphological characteristics of the various fungi organisms starting from the fungal colony (the nature of growth, color, texture \& the color of the opposite surface), if there are any secretions or stone objects on the surface of the colony, the shape of the fungal carrier (texture \& dimensions) the phialides (distribution \& number of layers) and the fungal spores (shape \& dimensions) [22-25]. And then, calculating the number of the fungal spores per $1 \mathrm{~g}$ of the studied material, as well as the spore's frequency according to famous equations in mycology $[21,26]$.

\section{Fungal toxicity tests}

The fungal isolates were grown on the liquid Czapek environment in $250 \mathrm{~mL}$ glass flasks, and they were incubated for 20 days at $(25-28)^{\circ} \mathrm{C}$. and then, the developing fungal mycelium was mixed on the nutritional media and was filtered through filtering papers to test the fungal toxicity on the germination of the chickpeas \& maize seeds by soaking the seeds in the fungal abstract after being superficially sterilized with alcohol, and then, 15 seeds were put on sterile water-soaked filtering paper and placed in a $4 \mathrm{~cm}$ petri dishes by 4 dishes for each fungal extract. The ratio of germination, the length of the hypocotyl and the radicle were recorded every day and compared to the witness sample (a non-infected nutritional environment). And also, the effect of toxicity on the activity of the bacteria Bacillus sp. was tested by injecting the PDA environment with the bacteria before the hardening of agar at $45^{\circ} \mathrm{C}$ and then pouring the infected medium in petri dishes and placing 5 scrapes of $0.5 \mathrm{~cm}$ filtering paper soaked in fungal abstract, prepared as previously, and also by 4 dishes for each fungal isolate, and then placing the dishes in an incubator at $30{ }^{\circ} \mathrm{C}$ for 24 hours and recording the diameter of the circles around the scrapes to see the effect of the fungal abstract on the activity of the bacteria [19,21].

\section{Results and Discussion}

The results of the analysis during the period $2011-2012$ demonstrated that most of the tested samples showed contamination with fungi in different degrees ranging from $1 \times 10^{2}-5 \times 10^{7}$ spore/gram food substance (Table 1). Results indicated that $100 \%$ of the thyme \& nuts samples showed fungal contamination that ranged from $7 \times 10^{2}-5 \times 10^{7}$, followed by potato \& maize chips samples with a contamination ratio of $79.2 \%$ and a degree ranged from $3 \times 10^{2}-1.5 \times 103$ while it was $73.5 \%$ in biscuit samples and with a degree of contamination ranged from $1 \times 10^{2}-3.7 \times 10^{3}$ and finally came the candy \& dried milk samples with a ratio of $42.5 \%$ and a frequency ranged from $3 \times 10^{2}-3.6 \times 10^{2}$. Results showed that in spite of the high contamination ratios of the tested samples, the overall levels of contamination were relatively low since only $2.3 \%$ of the tested samples exceeded a degree of 410 spore/gram substance of food. Noting that some countries don't allow the import of materials with a degree of fungal contamination that exceeds 310 spore/1 gram seeds, and thus, it's necessary to conduct periodic inspection on children's foods traded in the local markets and protect those foods from the contamination sources during all stages of manufacture \& production, especially in the conditions of direct consumption [3].

\begin{tabular}{|c|c|c|c|c|c|}
\hline $\begin{array}{c}\text { Food } \\
\text { substance }\end{array}$ & $\begin{array}{c}\text { Number of } \\
\text { tested samples }\end{array}$ & $\begin{array}{c}\text { Number of } \\
\text { contaminated } \\
\text { samples }\end{array}$ & $\begin{array}{c}\text { The ratio of fungal } \\
\text { contamination in } \\
\text { the tested samples } \\
\mathbf{( \% )}\end{array}$ & $\begin{array}{c}\text { The degree } \\
\text { of fungal } \\
\text { contamination } \\
\text { (spore / gram) }\end{array}$ & $\begin{array}{c}\text { The dominant fungal } \\
\text { species }\end{array}$ \\
\hline Thyme \& nuts & 35 & 35 & 100 & $7 \times 10^{2}-5 \times 10^{7}$ & $\begin{array}{c}\text { A.flavus, A.niger, } \\
\text { A.carbonarius, } \\
\text { P.cyclopium, Alternaria } \\
\text { alternate, R.stolonifer }\end{array}$ \\
\hline Biscuits & 45 & 33 & 73.3 & $1 \times 10^{2}-3.7 \times 10^{3}$ & $\begin{array}{c}\text { A.flavus, A.niger,A. } \\
\text { carbonarius, } \\
\text { P.cyclopium, R.stolonifer }\end{array}$ \\
\hline $\begin{array}{c}\text { Potato \& } \\
\text { maize chips }\end{array}$ & 53 & 42 & 79.2 & $3 \times 10^{2}-1.5 \times 10^{3}$ & $\begin{array}{c}\text { A.flavus, A.niger, } \\
\text { P.cyclopium, R.stolonifer }\end{array}$ \\
\hline $\begin{array}{c}\text { Candy \& } \\
\text { Dried milk }\end{array}$ & 40 & 17 & 42.5 & $3 \times 10^{2}-3.6 \times 10^{2}$ & $\begin{array}{c}\text { P.cyclopium, } \\
\text { A.alternate, M. } \\
\text { racemosus, R.stolonifer }\end{array}$ \\
\hline
\end{tabular}

Table 1: The degree of the fungal contamination of children's foods and the dominant species. The period 2011-2012. Al-Hasaka province 
An Isolation \& a classification has been done to 21 species belonged to 5 genera, 4 families, 3 orders \& 2 classes of fungi which are Hyphomycetes and Zygomycetes (Table 2), the largest number of the isolated fungal species belonged to the genus Aspergellus (7 species) and Penicillium (6 species), a lesser number to the genus Fusarium (3 species) and a single species to each of the rest genera: Alternaria, Cladosporium, Stemphilium, Mucor and Rhizopus.

\begin{tabular}{|c|c|c|c|c|}
\hline \multirow{2}{*}{ Class } & Order & Family & Genus & $\begin{array}{c}\text { Number of } \\
\text { species }\end{array}$ \\
\hline \multirow{2}{*}{ Hyphomycetes } & \multirow{2}{*}{ Hyphomycetales } & \multirow{2}{*}{ Moniliaceae } & Aspergillus & 7 \\
\cline { 4 - 5 } & & & Penicillium & 6 \\
\cline { 4 - 5 } & & \multirow{2}{*}{ Dematiace343a e } & Cladosporium & 1 \\
\cline { 4 - 5 } & & & Alternaria & 1 \\
\cline { 4 - 5 } & Tuberculariales & Tuberculariaceae & Fusarium & 3 \\
\hline \multirow{2}{*}{ Zygomycetes } & Mucorales & Mucoraceae & Mucor & 1 \\
\cline { 4 - 5 } & & & Rhizopus & 1 \\
\hline 2 & 3 & 4 & 8 & 21 \\
\hline
\end{tabular}

Table 2: Classification record of fungal species isolated from children'sfoods. The period $2011-2012$. Al-Hasaka province

The frequency of the fungal species on all tested food samples was recorded. The frequency degrees varied according to the food substance, 18 fungal species from thyme \& nuts samples were isolated and classified, the species A.flavus, A.niger and P.cyclopium showed high frequency, followed by A.carbonariusus, A.alternate and A.stolonifer with a moderate frequency whereas the rest of the species showed the lowest frequency (Table 3). 13 fungal species were isolated and classified from the biscuits samples and the same number from the potato \& maize chips samples. A high frequency of the species A.niger was recorded on all the mentioned samples, followed by the species A.flavus, P.cyclopium and R.stolonifer with a moderate frequency, while the rest of the species showed a lower frequency. Also 10 fungal species were isolated and classified from the candy \& dried milk samples with lesser contamination degrees, as a moderate frequency was recorded for the species A.flavus, P.cyclopium, A.alternate, M.racemosus and R.stolonifer while it was low for the rest of the species.

\begin{tabular}{|c|c|c|c|c|c|}
\hline Genus & Species & Thyme \& nuts & Biscuits & $\begin{array}{l}\text { Potato \& maize } \\
\text { chips }\end{array}$ & $\begin{array}{l}\text { Candy \& } \\
\text { dried milk }\end{array}$ \\
\hline \multirow{7}{*}{ Aspergillus } & A. candidus Link & + & + & + & - \\
\hline & $\begin{array}{c}\text { A. carbonarius (Bainier) } \\
\text { Thom }\end{array}$ & ++ & + & - & - \\
\hline & A. flavus Link & +++ & + & ++ & ++ \\
\hline & $\begin{array}{c}\text { A. foetidus (Naka.)Thom et } \\
\text { Raper }\end{array}$ & + & - & + & - \\
\hline & A. fumigatus Fres. & + & - & - & - \\
\hline & A. niger $v$. Tiegh & +++ & +++ & +++ & + \\
\hline & A. ochraceus Wilhelm & + & - & + & - \\
\hline \multirow{6}{*}{ Penicillium } & P. cyclopium Westl. & +++ & ++ & ++ & ++ \\
\hline & P. citrinum Thom & + & + & - & - \\
\hline & P. martensii Biourge & + & - & + & - \\
\hline & P. veridicatum Westl. & + & - & - & - \\
\hline & P. Hordai Stolk & + & - & - & + \\
\hline & P. purpurogenum Stoll & - & + & - & - \\
\hline Alternaria & A. alternate Nees et Neerg. & ++ & + & + & ++ \\
\hline Cladiosporium & $\begin{array}{l}\text { C.brevi-compactum Pidopl. } \\
\text { et Deniak }\end{array}$ & + & - & - & + \\
\hline Stemphilium & S. botryosum Wallr. & + & + & + & - \\
\hline \multirow{3}{*}{ Fusarium } & F. avenaceum (Fr.) Saac. & + & + & + & - \\
\hline & F. moniliforme Sheld. & - & + & + & + \\
\hline & F. oxysporum Schlect. & - & + & + & + \\
\hline Mucor & M. racemosus Fres. & + & - & - & ++ \\
\hline Rhizopus & R.stolonifer (Her.) Vuill & ++ & ++ & ++ & ++ \\
\hline Sum & & 18 & 13 & 13 & 10 \\
\hline
\end{tabular}

Note: There is no toxicity + low toxicity, ++ moderate toxicity, +++ high toxicity $(-=0 \%,+=1-25 \%,++=26-50 \%,>50 \%)$

Table 3: Record of the isolated fungal species and their frequency on children's foods. The period $2011-2012$. Al-Hasaka province 
Table 3 also indicates that the frequency has been recorded for the species A.flavus, A.niger, P.cyclopium, A.alternate and R.stolonifer in all tested food samples. And the rest fungal species showed varied frequencies on the tested substances that some species were isolated from only specific food substances and not the others as the species P.purpurogenum from the biscuits samples only, while the species A.candidus, A.flavus, A.niger, P.cyclopium, A.alternate, S.botryosum, F.avenaceum and P.stolonifer showed frequency on all substances except candy \& dried milk samples. Toxicity tests for 82 fungal isolates belonged to the species A.flavus (28 isolates), A.niger (10), A.ochraceus (5 isolates), Penicillium spp (15 isolates) A.alternate (7 isolates), and Fusarium spp (17 isolates) on the vitality of chickpeas \& maize seeds, and the activity of Bacillus spp bacteria in laboratory conditions, have indicated that 26 fungal isolates, $(31.7 \%)$ of all the isolates, showed toxic properties in varying degrees (Table 4 ), which indicates that the tested isolates have produced substances with toxic effects on the germination of chickpeas \& maize seeds, as well as on the Bacillus spp bacteria to the nutritional cultures.

\begin{tabular}{|c|c|c|c|c|c|c|}
\hline \multirow{2}{*}{ Fungal species } & \multirow{2}{*}{$\begin{array}{c}\text { Number of } \\
\text { tested } \\
\text { isolates }\end{array}$} & \multirow{2}{*}{$\begin{array}{c}\text { Number of } \\
\text { isolates with } \\
\text { Toxic properties }\end{array}$} & \multirow{2}{*}{$\begin{array}{c}\text { \% of the toxic } \\
\text { isolate }\end{array}$} & & \multicolumn{3}{|c|}{ Level of toxicity } \\
\cline { 5 - 7 } & & & & $\begin{array}{c}\text { Chickenpeas } \\
\text { Seeds }\end{array}$ & Maize Seeds & Bacillus Sp \\
\hline A. flavus & 28 & 12 & 42.9 & + & ++ & ++ \\
\hline A.niger & 10 & 2 & 20 & + & + & + \\
\hline A. ochraceus & 5 & 0 & 0 & - & - & - \\
\hline Penicillium spp & 15 & 3 & 20 & - & + & + \\
\hline A.alternate & 7 & 2 & 28.6 & - & + & + \\
\hline Fusarium spp & 17 & 7 & 41.2 & + & +++ & +++ \\
\hline sum & 82 & 26 & 31.7 & & & \\
\hline
\end{tabular}

Note: There is no toxicity + low toxicity, ++ moderate toxicity, +++ high toxicity 14

Table 4: Results of toxicity tests of some fungal isolates from children's foods on the germination of chickpeas \& maize seeds, and Bacellus spp bacteria. The period 2011

We can conclude from the results of this study that, different kinds of children's foods are affected by a wide variety of fungi which were isolated for the first time in Syria. Those fungi often have toxic properties through their secretions during their stages of growth and these toxic secretions are called Mycotoxins. The results of the biological tests have pointed to the toxic activity for some fungal species, and thus, the issue of children's foods contamination with fungi and their toxic secretions should be taken into consideration because of their effect on first, the quality of food and second, the health of children, and that's by taking all the necessary precautions to prevent the growth \& the activity of these fungi in foods. Also, worldwide must making efforts to regulate toxins values to lower the risk of toxicity impacts on human health. Because human may exposure to pesticides from many ways, such as ingestion, inhalation, and dermal contact, it is important to examine toxicity standards by considering all major exposure pathways [27,28].

\section{References}

1. Agrios G (2005) Plant Pathology (5th Edn) Elsevier Academic Press, Massachussetts, USA.

2. Youssef OA (2002) Aflatoxins (definition, characteristics, original source, poisonous and protection from aflatoxins). J Arab Agr Eng N 55: 29-34.

3. Totelian BA (1985) Atsenga zagraznenyia peshevie praducti mycotoxinami. Moscow T 2.

4. Wilson DM, Bell DK (1984) Aflatoxin production by Aspergillus flavus and Aspergillus parasiticus on visibly sound rehdrated peanut, corn and soybean seed. Peanut Sci T 11: 43-5.

5. Lacey J, Hill ST, Edwards MA (1980) Micro-organisms in stored grains: their enumeration and significance// Trop. Prod Inform 39 : $19-33$.

6. Sander TH, Davis ND, Diener UL (1968) Effect of carbon dioxid, temperature and relative humidity on production of aflatoxin in peanut. J Am Oil Chem Soc 45: 683-5.

7. Herzberg M (1970) Environmental factor affecting the production of aflatoxin In: Proceedings of the First US- Japan Conference on "Toxic Microorganisms", Washington: DC, US Govt Printing Office, USA.

8. Van Nieuwenhuize JP, Herber FM, De Bruin A, Meyer PB, Duba WC (1973) Cancers in men following a long-term Low-Level exposure to aflatoxins in indoor air. T Soc Geneeskd 50: 754-60.

9. Hartley RD, Nesbitt BF, Kelly JO (1963) Toxic metabolites of Aspergillus flavus. Nature (Lond.) 198: 1056-8.

10. Hesseltine CW, Sorensen WG, Smith M (1970) Taxonomic studies of the aflatoxin producing strains in the Aspergillus flavus group. Mycologia 62: 123-32.

11. Miller JK, Hacking A, Harrison J, Gross VJ (1973) Stillbirths neonantalmortality and small litters in pigs associated with the ingestion of Fusarium toxin by pregnant sows. Vet Rec 93: 555-9.

12. Gould RF (1976) Mycotoxins and other fungal related food problems. Washington DC, USA.

13. Shipilova N, Evashenko F (2000) Species of Fusarium in Russia. Leningrad 277-9.

14. Youssef OA, Grigorian KM, Osipian LL (1999a) Specific composition and toxigenic activity of micromycetes-contaminants of dry seed of bean cultures in Armenia, Holds the 39th week of science, 6-11 November, Damascus, Syria.

15. Youssef OA, Grigoryan KM, Osipian LL (1999b) The specific composition of mycobiota contaminating wheat grains distributed in Armenia. Problem of modern botany and mycology, Yerevan 169-73. 
16. Shimoda W (1979) In: Conference on mycotoxins in animal feeds and grains related to animal health, Rockville Publisher, USA.

17. FAO (1979) Perspective on mycotoxins. Rome 167.

18. Youssef OA (2000) Dengerous mycobiota and mycotoxins produced by corn, Proceedings of republican. Youth scientific conference, Yerevan 35-8.

19. Rodricks JV, Hesseltine CW, Mehlman MA (1977) Mycotoxins in human and health. Park Forest South, Illinois, Pathotox Publishers Inc, USA.

20. Norme Francaise NF ISO 6798-91., 1993. Cereales, legumneuses et products derves. Denobreme des bakteries, levures et moisissures, AFNOR, Paris, France.

21. Doudka IA, Vasser SP, Ellanskaya IA (1982) Methodi experementalnoi mycology. Nawkovo doumka Kiev 552.

22. Ellis MB (199) Dematiaceous hyphomycetes, Commonwealth.

23. Billai VI (1977) Fusarium, Kiev, 443 p.

24. Zillinsky FJ (1983) Common diseases of small grain cereals (A guide to identification), CIMMYT, Mexico.

25. Billai TI, Koval EZ (1988) Aspergelli (apredelitel), Nawkovo 428 doumka, Kiev, 204p.

26. El Kady IA, Abdel-Hafez ZN, El-Maraghy SS (1982) Contribution to the fungal flora of cereal grains in Egypt. Mycopathologia 77: 103-9.

27. Li Z (2018) Health risk characterization of maximum legal exposures for persistent organic pollutant (POP) pesticides in residential soil: An analysis. J Envir Manag 205: 163-73.

28. Li Z, Jennings A (2017) Implied Maximum Dose Analysis of Standard Values of 25 Pesticides Based on Major Human Exposure Pathways. AIMS Public Health 4: 383-98.

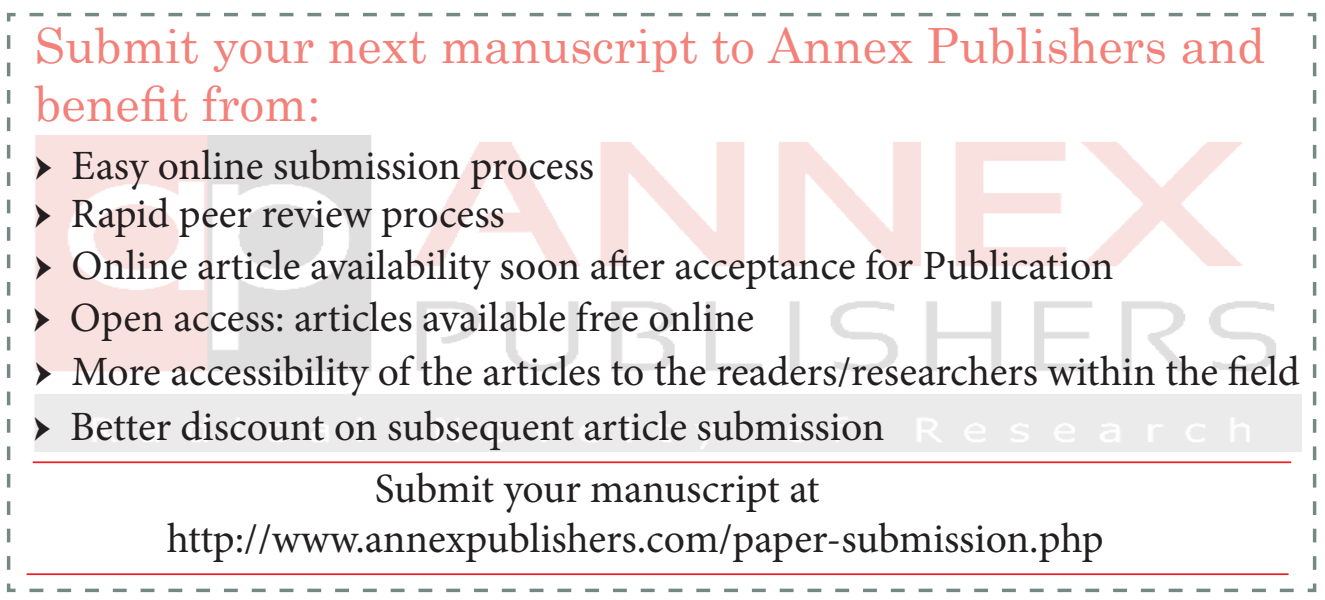

